English Heritage and the Amenity Societies, which preferred the use of ternecoated steel, were only prepared to countenance the use of Sarnafil on the basis that it was a temporary and reversible solution and urged that the faculty only be granted for a period of 10 years.

The chancellor refused to impose the time limit on the faculty on the basis that to require the removal of the Sarnafil before the expiry of its natural life span would be wasteful and an inappropriate stewarding of resources. He further chose not to impose any condition in relation to any future roofing material, stating that such questions were a matter for determination by the Consistory Court at that time, having regard to circumstances prevailing then. $[\mathrm{RA}]$

doi:10.1017/So956618X13000161

\title{
Eweida and others v United Kingdom
}

European Court of Human Rights, 15 January 2013

Freedom of religion - workplace - Christian symbols - civil partnerships

The Court considered four conjoined cases involving the right to manifest one's religion under Articles 9 (thought, conscience and religion) and 14 (prohibition of discrimination) of the European Convention on Human Rights. Ms Nadia Eweida, Ms Shirley Chaplin and Mr Gary McFarlane relied on Article 9, taken alone and in conjunction with Article 14 (prohibition of discrimination), while Ms Lillian Ladele complained only under Article 14 taken in conjunction with Article 9.

Ms Eweida, a check-in clerk employed by British Airways (BA), had been suspended from work for wearing a visible cross on a chain, in contravention of the company's uniform policy, but had later been reinstated after BA had decided to allow the display of authorised religious symbols, including the cross. However, BA had refused to compensate her for loss of earnings during her suspension. The Court of Appeal had held that BA's refusal to allow her to wear her cross had not been indirect discrimination contrary to the Employment Equality (Religion or Belief) Regulations 2003 ('the 2003 Regulations') because inconvenience to a single individual did not constitute a disadvantage that 'puts or would put persons of the same religion or belief ... at a particular disadvantage when compared with other persons' for the purposes of the Regulations.

Ms Chaplin, a nursing sister, had refused on religious grounds to stop wearing a crucifix necklace with her uniform, contrary to the Royal Devon and Exeter Foundation NHS Trust's health and safety policy (based on Department of Health guidance) that 'No necklaces will be worn to reduce the 
risk of injury when handling patients' and was therefore redeployed in a post in which she was not subject to the same restrictions. An Employment Tribunal had held that she had not been subjected to direct or indirect discrimination contrary to the provisions of the 2003 Regulations.

Ms Ladele, a registrar employed by Islington Borough Council, had refused on religious grounds to conduct civil partnership ceremonies. The Court of Appeal had held that she had been neither directly nor indirectly discriminated against nor harassed contrary to the 2003 Regulations, and that, except in the limited circumstances provided for in Regulation 14, the prohibition of discrimination in the Equality Act (Sexual Orientation) Regulations 2007 took precedence over any right that she might otherwise have by virtue of her religious belief to practise discrimination on the ground of sexual orientation.

Mr McFarlane had been employed as a counsellor by Relate Avon. He had refused on religious grounds to offer psycho-sexual counselling to same-sex couples and had been dismissed. The Employment Appeal Tribunal had concluded that he had not suffered direct or indirect discrimination under the 2003 Regulations nor been unfairly dismissed.

The Government argued that, under existing case law, Article 9 did not protect every action motivated by religion or belief: actions were only protected if they were part of the practice of a religion in a generally recognised form. Neither displaying a cross nor refusing to give psycho-sexual therapy to same-sex couples was the practice of religion in a generally recognised form. Even if that were not the case, when individuals voluntarily accepted employment that did not accommodate their religious practice but had other means to practise their religion without undue hardship, the Strasbourg case law made clear that there would be no interference with Article 9. Ms Eweida and Mr McFarlane were employed by private companies and there had been no allegation of direct interference by the state. Finally, all four employers had acted proportionately in response to a legitimate aim in each case.

The Court (Bratza and Thór Björgvinsson JJ dissenting) held that Ms Eweida had suffered an interference with her right to manifest, contrary to Article 9. BA's actions had been disproportionate and the Court of Appeal had not struck the correct balance in its ruling. However, in Ms Chaplin's case, though she also had suffered an interference with her right to manifest, health and safety on a hospital ward were inherently of a greater magnitude than the uniform policy applied in respect of Ms Eweida, and the NHS Trust had not acted unreasonably or disproportionately.

In the case of Ms Ladele, though the consequences of her refusal had been serious, the local authority's policy aimed to secure the rights of others that are also protected under the Convention; the national authorities - the local authority employer and the domestic courts - had not exceeded the margin 
of appreciation available to them. The Court (De Gaetano and Vučinić JJ dissenting) dismissed her claim.

Mr McFarlane had enrolled on Relate's postgraduate training programme in psycho-sexual counselling voluntarily, even though he knew that, because of Relate's policy of providing a service without discrimination, he would not be able to filter out clients on the ground of sexual orientation. The state authorities had a wide margin of appreciation in such circumstances and it had not been exceeded in Mr McFarlane's case. His claim was dismissed unanimously. [Frank Cranmer]

For a detailed Comment on this judgment see M Hill, 'Religious symbolism and conscientious objection in the workplace: an evaluation of Strasbourg's judgment in Eweida and others v United Kingdom', (2013) 15 Ecc LJ 191-203. 